\title{
TUSC2 wt Allele
}

National Cancer Institute

\section{Source}

National Cancer Institute. TUSC2 wt Allele. NCI Thesaurus. Code C54391.

Human TUSC2 wild-type allele is located in the vicinity of 3p21.3 and is approximately $3 \mathrm{~kb}$ in length. This allele, which encodes tumor suppressor candidate 2 protein, plays a putative role in cell cycle arrest and the induction of apoptosis. Loss of TUSC2 gene function is associated with several types of lung cancer. 